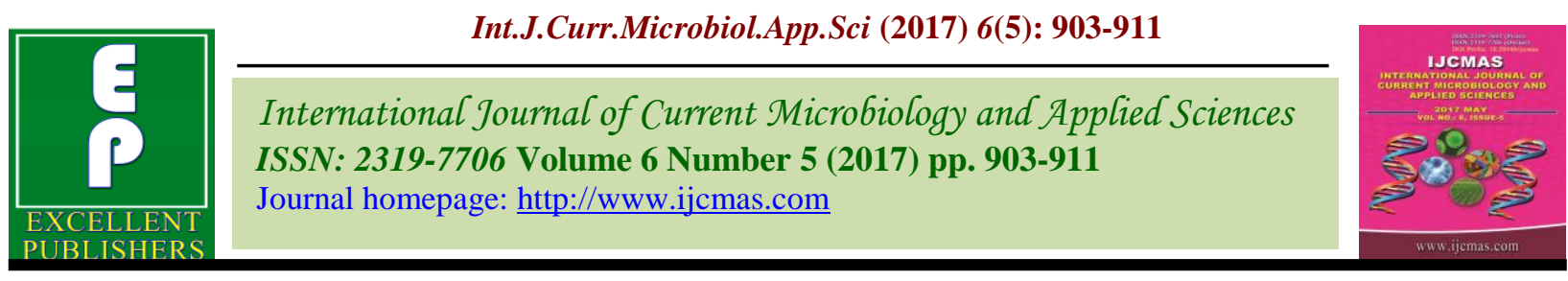

Original Research Article

https://doi.org/10.20546/ijcmas.2017.605.100

\title{
Triple Test Cross for Yield and Quantitative Components in Brinjal (Solanum melongena L.)
}

\author{
Smita Kumari*, K.S. Chandel and Aachal Chauhan \\ Department of Vegetable Science and Floriculture, CSK HPKV, Palampur, \\ Himachal Pradesh, 176 062, India \\ *Corresponding author
}

\begin{tabular}{|c|c|}
\hline & A B S T R A C T \\
\hline Keywords & \multirow{4}{*}{$\begin{array}{l}\text { The success of vegetable breeding operations mainly depends upon the nature and extent } \\
\text { of genetic components of variation. Thus it is imperative to have reliable estimates of such } \\
\text { components in order to formulate an efficient breeding strategy. In the present study, the } \\
\text { components of genetic variation were studied in AN (Arka Nidhi) and SN (Singh Nath) for } \\
\text { quantitative characters. The estimates of both additive and dominance components were } \\
\text { significant for all the characters except days to } 50 \text { per cent flowering, fruit diameter, } \\
\text { number of branches per plant and pedicel length. Epistasis }(i) \text { and }(j+l) \text { type was } \\
\text { significant in all the traits except except fruit diameter }(\mathrm{cm}) \text {. The degree of dominance } \\
(H / D)^{1 / 2} \text { was in the range of over dominance for marketable fruit yield per plant, number of } \\
\text { marketable fruits per plant, fruit length }(\mathrm{cm}) \text {, plant height }(\mathrm{cm}) \text {, number of branches per } \\
\text { plant and fruit weight }(\mathrm{g}) \text { where as the presence of partial dominance for days to } 50 \text { per } \\
\text { cent flowering, days to first picking, fruit diameter }(\mathrm{cm}) \text { pedicel length }(\mathrm{cm}) \text { and bacterial } \\
\text { wilt incidence. }\end{array}$} \\
\hline $\begin{array}{l}\text { Triple test cross, } \\
\text { additive, } \\
\text { dominance, } \\
\text { epistasis. }\end{array}$ & \\
\hline Article Info & \\
\hline $\begin{array}{l}\text { Accepted: } \\
04 \text { April } 2017 \\
\text { Available Online: } \\
10 \text { May } 2017\end{array}$ & \\
\hline
\end{tabular}

\section{Introduction}

Brinjal is a well known vegetable crop and it is generally grown in the tropical, sub tropical and warm temperate area of the world. It is a good source of minerals and vitamins in the tropical diets. Brinjal is otherwise called as egg plant and it originates from India. It is an important vegetable in India, china and Japan. The botanical name of brinjal is Solanum melongena $\mathrm{L}$. and it has a wide range of varieties. Most of the genetic models have been developed to estimate the component of continuous variation, have as one of their assumption the absence of epistasis. In general, Epistasis causes hidden quantitative genetic variation in natural populations and could be responsible for the small additive effects (Mackay, 2014). In fact a good genetic model, enables the breeder to have precise and unbiased estimates of all the components of genetic variance. The triple test cross biometrical design proposed by Kearsey and Jink (1968), which is an extension of North Carolina Design-III (NCD-III) of Comstock and Robinson (1952) which envisages the exact nature and magnitude of epistatic interactions viz., additive $\mathrm{x}$ additive, additive $\mathrm{x}$ dominance and dominance $\mathrm{x}$ dominance gene effects. TTC (Triple test cross) analysis provides unambiguous test for the presence of epistasis regardless of gene frequencies, degree of inbreeding and linkage relationships. The design has wide 
applicability as it can be used to investigate both segregating and non-segregating populations arising from different generations such as $F_{2}$, backcross and homozygous lines. TTC method has many advantages over other multiple mating designs, in this design the number of crosses does not increase tremendously with increase in number of other mating designs. Therefore the present study was undertaken to get an insight into the genetic factors underlying expression of quantitative traits.

\section{Materials and Methods}

The experimental material consisted of (a) AN (Arka Nidhi) and SN (Singh Nath), and their respective $F_{2}$ 's were utilized. Ten plants were randomly taken from each $F_{2}$ population, designated as $10 \mathrm{Pi}$ lines and crossed to their respective female testers namely $L_{1}, L_{2}$ and $L_{3} . L_{1}$ and $L_{2}$ are the inbred lines of the respective $F_{1}$ and its $F_{2}$, where as $\mathrm{L}_{3}$ is the $\mathrm{F}_{1}$ produced from them. The crossing plan thus yielded 3 n progenies comprising 30 crosses for each set of experiment in a triple test cross mating design. The 30 families $\left(\mathrm{L}_{1 \mathrm{i}}\right.$, $\mathrm{L}_{2 \mathrm{i}}$ and $\mathrm{L}_{3 \mathrm{i}}$ ) along with ten $\mathrm{Pi}$ lines and three female testers for each set of experiment were grown in a randomised block design (RBD) with three replications during kharif season 2015-16 at Vegetable Research Farm, CSKHPKV, Palampur. Each experimental plot comprised two meters long rows/replication with inter and intra plant spacing of 30 and $7.5 \mathrm{~cm}$ respectively. The observations were recorded from the ten competitive plants, taken at random from each entry in each replication for the following traits viz., marketable fruit yield per plant, number of marketable fruits per plant, days to 50 per cent flowering, days to first picking, pedicel length $(\mathrm{cm})$, fruit length $(\mathrm{cm})$, fruit weight $(\mathrm{g})$, fruit diameter $(\mathrm{cm})$, number of branches per plant and plant height. The mean values of each set of experiment for different traits were subjected to the analysis of variance as per randomised block design. Analysis was based on the following model given by Panse and Sukhatme (1984).The data were analysed for (i) the analysis of variance triple test cross design (Kearsey and Jinks, 1968), (ii) analysis of variance to test epistasis and its components (Jinks and Perkins, 1970), (iii) analysis of variance for testing of adequacy of testers (Jinks et al., 1969; Jinks and Virk, 1977; Virk and Jinks, 1977) and (iv) estimation of additive and dominance components of variation (Jinks and Perkins, 1970). Kearsey and Jinks (1968) did not suggest the partitioning of epistasis. This was suggested by Jinks and Perkins (1970). Further the test $\left(\mathrm{L}_{1 \mathrm{i}}+\mathrm{L}_{2 \mathrm{i}}-2 \mathrm{~L}_{3 \mathrm{i}}\right)$ is non significant, this means that there is no detectable epistasis and the testers are adequate and the estimates of genetic parameters would be unbiased, if the $\left(\mathrm{L}_{1 \mathrm{i}}+\right.$ $\mathrm{L}_{2 \mathrm{i}}-2 \mathrm{~L}_{3 \mathrm{i}}$ ) is significant, this indicates that epistasis is present, but we cannot be sure of the adequacy or inadequacy of the testers.

\section{Results and Discussion}

The means of fruitt yield per plant are presented in Table 1 and the analysis of variance is given in table 2 , which indicated significant differences among the progenies, $\mathrm{Pi}$ lines and testers. The fruit yield per plot ranged from $450.57\left(\mathrm{P}_{2} \times \mathrm{L}_{1}\right)$ to $725.25 \mathrm{~g}\left(\mathrm{P}_{6}\right.$ $\left.\mathrm{x} \mathrm{L}_{1}\right)$ in progenies and $498.79\left(\mathrm{P}_{2}\right)$ to $580.75 \mathrm{~g}$ $\left(\mathrm{P}_{6}\right)$ in $\mathrm{Pi}$ lines. The yield per plant of female testers ranged from $504.80 \mathrm{~g}\left(\mathrm{~L}_{2}\right), 560.96 \mathrm{~g}$ $\left(\mathrm{L}_{1}\right)$ and $545.40 \mathrm{~g} \mathrm{AN} \times \mathrm{SN}\left(\mathrm{F}_{1}\right) \mathrm{L}_{3}$. The cross combination $\left(\mathrm{P}_{6} \times \mathrm{L}_{1}\right),\left(\mathrm{P}_{6} \times \mathrm{L}_{3}\right),\left(\mathrm{P}_{6} \times \mathrm{L}_{2}\right),\left(\mathrm{P}_{4}\right.$ $\mathrm{x} \mathrm{L} 1),\left(\mathrm{P}_{3} \times \mathrm{L}_{1}\right),\left(\mathrm{P}_{3} \times \mathrm{L}_{2}\right),\left(\mathrm{P}_{3} \times \mathrm{L}_{3}\right),\left(\mathrm{P}_{7} \times \mathrm{L}_{2}\right)$, $\left(\begin{array}{lll}\mathrm{P}_{1} & \mathrm{x} & \mathrm{L}_{3}\end{array}\right)$ and $\left(\mathrm{P}_{1} \times \mathrm{L}_{2}\right)$ were significantly superior to their respective better parent. Eight cross combinations produced significantly higher marketable fruit yield per plant than the cultivar Arka Nidhi (AN), while 21 cross combinations significantly exceeded the cultivar Singh Nath (SN) in 
marketable fruit yield per plant. The maximum increase in fruit yield was to the extent of 29.28 and 43.67 per cent over AN and $\mathrm{SN}$, respectively. Over the superior $\mathrm{Pi}$ line $\left(\mathrm{P}_{6}\right)$ and $\mathrm{L}_{3}$ tester, seven and 11 cross combinations exceeded significantly in marketable fruit yield per plant to the extent of 32.97 and 24.88 per cent, respectively. The result of epistasis and its components are presented in Table 3. The mean squares due to epistasis and its additive $\mathrm{x}$ additive (i), additive $x$ dominance $(j)$ and dominance $x$ dominance (l) genetic components of variation. The perusal of the table indicates that epistasis and its components $\mathrm{i}, \mathrm{j}$ and 1 were significant showing there by the importance of both epistasis and its components viz., additive $\mathrm{x}$ additive, additive $\mathrm{x}$ dominance and dominance $\mathrm{x}$ dominance genic interactions. The analysis of variance of sums and differences for the character were significant, suggesting the presence of both additive and dominance component of genetic variation for the inheritance of the trait. The comparison of $\mathrm{D}$ and $\mathrm{H}$ components revealed that $\mathrm{H}$ component was of greater magnitude than the D component and mean degree of dominance was in over-dominance range.

From the table 1 the mean value of days to 50 per cent flowering ranged from $59.67\left(\mathrm{~L}_{1}\right)$ to $71.00\left(\mathrm{~L}_{2}\right)$ in testers, $57.53\left(\mathrm{P}_{9}\right)$ to $71.25\left(\mathrm{P}_{3}\right)$ in $\mathrm{Pi}$ lines and $49.11\left(\mathrm{P}_{9} \mathrm{x} \mathrm{L}_{1}\right)$ to $73.77\left(\mathrm{P}_{3} \mathrm{X}\right.$ $\left.\mathrm{L}_{2}\right)$ in progenies. Among the progenies, the cross combinations $\left(\mathrm{P}_{9} \times \mathrm{L}_{1}\right),\left(\mathrm{P}_{9} \times \mathrm{L}_{3}\right),\left(\mathrm{P}_{8} \times\right.$ $\left.\mathrm{L}_{1}\right),\left(\mathrm{P}_{8} \times \mathrm{L}_{3}\right),\left(\mathrm{P}_{4} \times \mathrm{L}_{1}\right),\left(\mathrm{P}_{2} \times \mathrm{L}_{3}\right),\left(\mathrm{P}_{1} \times \mathrm{L}_{2}\right)$, $\left(\mathrm{P}_{10} \times \mathrm{L}_{1}\right),\left(\mathrm{P}_{6} \times \mathrm{L}_{1}\right),\left(\mathrm{P}_{6} \times \mathrm{L}_{3}\right),\left(\mathrm{P}_{4} \times \mathrm{L}_{3}\right),\left(\mathrm{P}_{3} \times\right.$ $\left.\mathrm{L}_{3}\right),\left(\mathrm{P}_{4} \times \mathrm{L}_{2}\right)$ and $\left(\mathrm{P}_{5} \times \mathrm{L}_{3}\right)$ manifested significantly less number of days to 50 per cent flowering than their respective better parent. The average value of days to $1^{\text {st }}$ Picking ranged from $67.22\left(\mathrm{~L}_{1}\right)$ to $77.67\left(\mathrm{~L}_{2}\right)$ in testers, $58.15\left(\mathrm{P}_{8} \times \mathrm{L}_{3}\right)$ to $78.25\left(\mathrm{P}_{3} \times \mathrm{L}_{2}\right)$ in progenies and $63.31\left(\mathrm{P}_{9}\right)$ to $76.15\left(\mathrm{P}_{3}\right)$ in $\mathrm{Pi}$ lines. Among the progenies, the cross combinations $\left(\mathrm{P}_{8} \times \mathrm{L}_{3}\right),\left(\mathrm{P}_{9} \times \mathrm{L}_{1}\right),\left(\mathrm{P}_{9} \times \mathrm{L}_{3}\right)$,
$\left(\mathrm{P}_{8} \times \mathrm{L}_{1}\right),\left(\mathrm{P}_{2} \times \mathrm{L}_{3}\right),\left(\mathrm{P}_{4} \times \mathrm{L}_{1}\right),\left(\mathrm{P}_{6} \times \mathrm{L}_{1}\right),\left(\mathrm{P}_{1} \mathrm{x}\right.$ $\left.\mathrm{L}_{1}\right),\left(\mathrm{P}_{10} \times \mathrm{L}_{1}\right),\left(\mathrm{P}_{6} \times \mathrm{L}_{3}\right)$ and $\left(\mathrm{P}_{4} \times \mathrm{L}_{3}\right)$ performed significantly better than their respective better parent. The maximum decrease in fruit picking was to the tune of 15.59 and 33.56 per cent over $\mathrm{AN}$ and SN, respectively, in relation to number of marketable fruits per plant ranged from 14.51 $\left(\mathrm{L}_{2}\right)$ to $21.17\left(\mathrm{~L}_{1}\right)$ in testers, $12.62\left(\mathrm{P}_{5}\right)$ to $22.35\left(\mathrm{P}_{8}\right)$ in $\mathrm{Pi}$ lines and $10.09\left(\mathrm{P}_{5} \times \mathrm{L}_{3}\right)$ to $25.30\left(\mathrm{P}_{8} \times \mathrm{L}_{1}\right)$ in progenies. The cross combinations $\left(\mathrm{P}_{8} \times \mathrm{L}_{1}\right),\left(\mathrm{P}_{8} \times \mathrm{L}_{3}\right),\left(\mathrm{P}_{1} \times \mathrm{L}_{1}\right)$, $\left(\mathrm{P}_{7} \times \mathrm{L}_{3}\right),\left(\mathrm{P}_{7} \times \mathrm{L}_{1}\right),\left(\mathrm{P}_{4} \times \mathrm{L}_{1}\right),\left(\mathrm{P}_{1} \times \mathrm{L}_{3}\right),\left(\mathrm{P}_{4} \times\right.$ $\left.\mathrm{L}_{3}\right),\left(\mathrm{P}_{2} \times \mathrm{L}_{2}\right),\left(\begin{array}{lll}\mathrm{P}_{6} & \times & \mathrm{L}_{2}\end{array}\right)$ and $\left(\mathrm{P}_{10} \times \mathrm{L}_{2}\right)$ produced significantly more number of marketable fruits per plant than their respective better parent. Eight cross combinations significantly surpassed the cultivar Arka Nidhi (AN), vis-a-vis 21 cross combinations out yielded in number of marketable fruits per plant over Singh Nath (SN) giving an increase in number of marketable fruits per plant to the extent of 19.50 and 74.36 per cent over $\mathrm{AN}$ and $\mathrm{SN}$, respectively. Over the superior $\mathrm{Pi}$ line $\left(\mathrm{P}_{8}\right)$ five crosses $\left(\mathrm{P}_{1} \times \mathrm{L}_{1}\right),\left(\mathrm{P}_{7} \times \mathrm{L}_{1}\right),\left(\mathrm{P}_{7} \times \mathrm{L}_{3}\right),\left(\mathrm{P}_{8}\right.$ $\left.\mathrm{x} \mathrm{L}_{1}\right)$ and $\left(\mathrm{P}_{8} \times \mathrm{L}_{3}\right)$ exceeded in number of marketable fruits per plant and the increase was to the extent of 29.21 and 24.32 per cent over $\mathrm{L}_{3}$ and best $\mathrm{Pi}$ line $\left(\mathrm{P}_{8}\right)$, respectively. The fruit length ranged from $16.61 \mathrm{~cm}\left(\mathrm{~L}_{1}\right)$ to $20.06 \mathrm{~cm}\left(\mathrm{~L}_{2}\right)$ in testers, $13.02 \mathrm{~cm}\left(\mathrm{P}_{9}\right)$ to $19.70 \mathrm{~cm}\left(\mathrm{P}_{7}\right)$ in $\mathrm{Pi}$ lines and $14.74\left(\mathrm{P}_{4} \times \mathrm{L}_{1}\right)$ to $24.62\left(\mathrm{P}_{7} \mathrm{x} \mathrm{L} \mathrm{L}_{2}\right)$ in progenies. Combinations $\left(\mathrm{P}_{7} \times \mathrm{L}_{2}\right)$ excelled the superior $\mathrm{Pi}$ line $\left(\mathrm{P}_{7}\right)$ in fruit length significantly. With the respect of fruit diameter, the mean value of $\mathrm{Pi}$ lines was in the range of $2.15 \mathrm{~cm}\left(\mathrm{P}_{1}\right)$ to $2.69 \mathrm{~cm}\left(\mathrm{P}_{4}\right)$ and in progenies it ranged from $1.90 \mathrm{~cm}\left(\mathrm{P}_{1} \mathrm{X}\right.$ $\left.\mathrm{L}_{2}\right)$ to $3.45 \mathrm{~cm}\left(\mathrm{P}_{4} \times \mathrm{L}_{3}\right)$. Among the progenies, the cross combinations $\left(\mathrm{P}_{4} \times \mathrm{L}_{3}\right)$, $\left(\mathrm{P}_{9} \times \mathrm{L}_{1}\right),\left(\mathrm{P}_{4} \times \mathrm{L}_{1}\right),\left(\mathrm{P}_{3} \times \mathrm{L}_{3}\right),\left(\mathrm{P}_{10} \times \mathrm{L}_{3}\right),\left(\mathrm{P}_{9} \mathrm{x}\right.$ $\left.\mathrm{L}_{3}\right),\left(\mathrm{P}_{5} \times \mathrm{L}_{3}\right),\left(\mathrm{P}_{8} \times \mathrm{L}_{1}\right),\left(\mathrm{P}_{10} \times \mathrm{L}_{1}\right),\left(\mathrm{P}_{6} \times \mathrm{L}_{1}\right)$ and $\left(\mathrm{P}_{3} \times \mathrm{L}_{1}\right)$ gave significantly higher fruit diameter than their respective better parent. The plant height varied from $80.84\left(\mathrm{~L}_{1}\right)$ to 
$91.25 \mathrm{~cm}\left(\mathrm{~L}_{2}\right)$ in tester, $74.18\left(\mathrm{P}_{2}\right)$ to $89.45 \mathrm{~cm}$ $\left(\mathrm{P}_{4}\right)$ in $\mathrm{Pi}$ lines and $72.58\left(\mathrm{P}_{1} \times \mathrm{L}_{2}\right)$ to 108.70 $\mathrm{cm}\left(\mathrm{P}_{4} \times \mathrm{L}_{2}\right)$ in progenies. $80.84 \mathrm{~cm}$. The cross combinations $\left(\mathrm{P}_{4} \times \mathrm{L}_{2}\right),\left(\mathrm{P}_{3} \times \mathrm{L}_{3}\right),\left(\mathrm{P}_{7} \mathrm{x}\right.$ $\left.\mathrm{L}_{2}\right),\left(\mathrm{P}_{4} \times \mathrm{L}_{3}\right),\left(\mathrm{P}_{3} \times \mathrm{L}_{2}\right),\left(\mathrm{P}_{2} \times \mathrm{L}_{2}\right),\left(\mathrm{P}_{5} \times \mathrm{L}_{2}\right)$, $\left(\mathrm{P}_{4} \times \mathrm{L}_{1}\right),\left(\mathrm{P}_{10} \times \mathrm{L}_{1}\right),\left(\mathrm{P}_{2} \times \mathrm{L}_{1}\right),\left(\mathrm{P}_{9} \times \mathrm{L}_{1}\right)$ and $\left(\mathrm{P}_{8} \times \mathrm{L}_{1}\right)$ was superior to its respective better parent/tester. Eleven cross combinations surpassed in plant height than cultivar Arka Nidhi (AN), while five cross combinations performed significantly better than the cultivar Singh Nath (SN). The maximum increase in plant height was 34.46 and 19.12 per cent over AN and SN, respectively. Eight cross combinations exhibited more plant height over the $\mathrm{L}_{3}$ tester, whereas seven cross combinations excelled in plant height over the best $\mathrm{Pi}$ line $\left(\mathrm{P}_{4}\right)$. The increase in plant height was to the extent of 21.52 and 22.21 per cent over Pi line $\left(\mathrm{P}_{4}\right)$ and $\mathrm{L}_{3}$ tester, respectively. In respect to number of primary branches, the cross combinations $\left(\mathrm{P}_{10} \times \mathrm{L}_{1}\right),\left(\mathrm{P}_{10} \times \mathrm{L}_{3}\right),\left(\mathrm{P}_{5} \mathrm{x}\right.$ $\left.\mathrm{L}_{1}\right),\left(\mathrm{P}_{1} \times \mathrm{L}_{2}\right),\left(\mathrm{P}_{1} \times \mathrm{L}_{1}\right),\left(\mathrm{P}_{1} \times \mathrm{L}_{3}\right),\left(\mathrm{P}_{8} \times \mathrm{L}_{1}\right)$, $\left(\mathrm{P}_{3} \times \mathrm{L}_{3}\right),\left(\mathrm{P}_{5} \times \mathrm{L}_{2}\right),\left(\mathrm{P}_{7} \times \mathrm{L}_{2}\right),\left(\mathrm{P}_{9} \times \mathrm{L}_{2}\right)$ and $\left(\mathrm{P}_{8} \times \mathrm{L}_{2}\right)$ were significantly superior to their respective better parent/tester. For the fruit weight, The cross combinations $\left(\mathrm{P}_{7} \times \mathrm{L}_{2}\right),\left(\mathrm{P}_{6}\right.$ $\left.\mathrm{x} \mathrm{L}_{2}\right),\left(\mathrm{P}_{6} \times \mathrm{L}_{1}\right),\left(\mathrm{P}_{4} \times \mathrm{L}_{2}\right),\left(\mathrm{P}_{10} \times \mathrm{L}_{2}\right),\left(\mathrm{P}_{7} \times \mathrm{L}_{1}\right)$, $\left(\mathrm{P}_{4} \times \mathrm{L}_{3}\right),\left(\mathrm{P}_{10} \times \mathrm{L}_{3}\right),\left(\mathrm{P}_{3} \times \mathrm{L}_{3}\right),\left(\mathrm{P}_{3} \times \mathrm{L}_{1}\right),\left(\mathrm{P}_{1} \times\right.$ $\left.\mathrm{L}_{2}\right),\left(\mathrm{P}_{9} \times \mathrm{L}_{1}\right)$ and $\left(\mathrm{P}_{2} \times \mathrm{L}_{1}\right)$ was superior to its respective better parent/tester. The maximum increase in fruit weight was 39.79 and 15.30 per cent over $\mathrm{AN}$ and $\mathrm{SN}$, respectively. Six and eight cross combinations were statistically at par for fruit weight with cultivar Arka Nidhi (AN) and Singh Nath $(\mathrm{SN})$, respectively. Over the $\mathrm{L}_{3}$ tester, 10 cross combinations produced significantly more fruit weight, while seven cross combinations excelled the superior $\mathrm{Pi}$ line $\left(\mathrm{P}_{7}\right)$ in fruit weight and the increase was observed to the tune of 23.99 and 12.52 per cent over $\mathrm{L}_{3}$ tester and $\mathrm{Pi}$ line $\left(\mathrm{P}_{7}\right)$, respectively. For pedicel length ranged from $5.28\left(\mathrm{~L}_{1}\right)$ to $7.02\left(\mathrm{~L}_{2}\right)$ in testers, $4.95\left(\mathrm{P}_{5}\right)$ to $6.90\left(\mathrm{P}_{9}\right)$ in $\mathrm{Pi}$ lines and $4.70\left(\mathrm{P}_{5} \times \mathrm{L}_{1}\right)$ to 7.96
$\left(\begin{array}{lll}\mathrm{P}_{9} & \mathrm{X} & \mathrm{L}_{2}\end{array}\right)$ in progenies. Twenty one cross combinations exhibited better pedicel length than the cultivar AN, whereas, seven cross combinations excelled in pedicel length than the cultivar SN. The maximum increase in pedicel length was to the extent of 50.75 and 13.39 per cent over AN and SN, respectively. In bacterial wilt incidence the cross combinations $\left(\mathrm{P}_{2} \times \mathrm{L}_{1}\right),\left(\mathrm{P}_{4} \times \mathrm{L}_{1}\right),\left(\mathrm{P}_{2} \times \mathrm{L}_{3}\right)$, $\left(\mathrm{P}_{6} \times \mathrm{L}_{2}\right),\left(\mathrm{P}_{7} \times \mathrm{L}_{3}\right),\left(\mathrm{P}_{4} \times \mathrm{L}_{2}\right),\left(\mathrm{P}_{9} \times \mathrm{L}_{3}\right),\left(\mathrm{P}_{6} \times\right.$ $\left.\mathrm{L}_{1}\right),\left(\mathrm{P}_{4} \times \mathrm{L}_{3}\right),\left(\mathrm{P}_{3} \times \mathrm{L}_{2}\right)$ and $\left(\mathrm{P}_{9} \times \mathrm{L}_{2}\right)$ were proved to be significantly superior to their respective better parent and the maximum decrease in bacterial wilt incidence was to the tune of 53.82 and 79.15 per cent over AN and $\mathrm{SN}$, respectively.

The existence of genetic variability among testers, parental lines and their progenies for marketable fruit yield per plant, days to 50 per cent flowering, days to $1^{\text {st }}$ Picking, number of marketable fruits per plant, fruit length, fruit diameter, plant height, number of branches per plant, fruit weight, pedicel length and bacterial wilt incidence. The progenies $\left(\mathrm{P}_{3} \mathrm{X}\right.$ $\left.\mathrm{L}_{1}\right),\left(\mathrm{P}_{3} \times \mathrm{L}_{2}\right),\left(\mathrm{P}_{2} \times \mathrm{L}_{3}\right),\left(\mathrm{P}_{5} \times \mathrm{L}_{2}\right),\left(\mathrm{P}_{7} \times \mathrm{L}_{2}\right)$, $\left(\mathrm{P}_{7} \times \mathrm{L}_{3}\right)$ and $\left(\mathrm{P}_{9} \times \mathrm{L}_{3}\right)$ exhibited significantly higher mean values marketable fruit yield per plant, number of marketable fruits per plant, fruit length, fruit diameter, fruit weight, number of branches per plant. Epistasis was observed for these characters showing thereby epistasis played significant role in the inheritance of these traits. These results are in line with those of Singh et al., (2002), Indiresh et al., (2005), Shinde (2007), Dhameliya and Dobariya (2009) and Sabolu et al., (2014). The manifestation of nonadditive genetic effects and general trend of increase indicated that positive heterotic effects are fisible.

The analysis of variance for detection of epistasis (Table 3) revealed that Epistasis ( $i$ ) and $(j+l)$ type was significant in all the traits except fruit diameter $(\mathrm{cm})$. 
Table.1 Mean values of the treatments for different characters in TTC progenies of AN (L1) and SN (L2)

\begin{tabular}{|c|c|c|c|c|c|c|c|c|c|c|c|}
\hline Treatments & $\begin{array}{l}\text { Marketable } \\
\text { fruit yield/ } \\
\text { plant (g) }\end{array}$ & $\begin{array}{l}\text { Days to } \\
50 \text { per } \\
\text { cent } \\
\text { flowering }\end{array}$ & $\begin{array}{l}\text { Days to } \\
\text { first } \\
\text { picking }\end{array}$ & $\begin{array}{c}\text { Number of } \\
\text { marketable } \\
\text { fruits } \\
\text { per plant }\end{array}$ & $\begin{array}{c}\text { Fruit } \\
\text { length } \\
(\mathbf{c m})\end{array}$ & $\begin{array}{l}\text { Fruit } \\
\text { dia- } \\
\text { meter } \\
(\mathrm{cm})\end{array}$ & $\begin{array}{l}\text { Plant } \\
\text { height } \\
\text { (cm) }\end{array}$ & $\begin{array}{l}\text { Number } \\
\text { of } \\
\text { branches } \\
\text { per } \\
\text { plant }\end{array}$ & $\begin{array}{l}\text { Fruit } \\
\text { weight } \\
\text { (g) }\end{array}$ & $\begin{array}{l}\text { Pedicel } \\
\text { length } \\
(\mathrm{cm})\end{array}$ & $\begin{array}{c}\text { Bacterial } \\
\text { wilt } \\
\text { incidence } \\
(\%)\end{array}$ \\
\hline $\mathrm{P}_{1} \times \mathrm{L}_{1}$ & 530.71 & 55.71 & 63.51 & 24.70 & 15.75 & 2.20 & 76.29 & 7.11 & 30.57 & 5.79 & 5.11 \\
\hline $\mathrm{P}_{1} \times \mathrm{L}_{3}$ & 565.77 & 57.71 & 65.51 & 21.37 & 16.32 & 2.28 & 80.71 & 6.99 & 26.26 & 5.66 & 6.44 \\
\hline $\mathrm{P}_{1} \times \mathrm{L}_{2}$ & 525.25 & 66.61 & 72.87 & 18.27 & 18.74 & 1.90 & 72.58 & 7.25 & 32.59 & 6.86 & 8.14 \\
\hline $\mathrm{P}_{2} \times \mathrm{L}_{1}$ & 450.57 & 65.79 & 74.18 & 17.99 & 19.78 & 2.59 & 82.71 & 5.97 & 30.96 & 6.91 & 3.79 \\
\hline $\mathrm{P}_{2} \times \mathrm{L}_{3}$ & 472.19 & 54.78 & 60.11 & 18.34 & 18.56 & 2.44 & 78.75 & 6.13 & 28.91 & 7.05 & 3.92 \\
\hline $\mathrm{P}_{2} \mathrm{X} \mathrm{L}_{2}$ & 494.19 & 66.36 & 71.54 & 17.95 & 21.82 & 2.58 & 94.72 & 5.17 & 24.70 & 7.18 & 4.21 \\
\hline $\mathrm{P}_{3} \times \mathrm{L}_{1}$ & 620.19 & 65.21 & 73.29 & 12.73 & 20.51 & 2.82 & 82.19 & 5.99 & 33.93 & 5.41 & 8.44 \\
\hline $\mathrm{P}_{3} \times \mathrm{L}_{3}$ & 592.92 & 59.74 & 69.38 & 15.72 & 17.12 & 2.99 & 101.22 & 6.92 & 35.79 & 4.94 & 10.92 \\
\hline $\mathrm{P}_{3} \times \mathrm{L}_{2}$ & 612.72 & 73.77 & 78.25 & 13.75 & 22.50 & 2.64 & 96.74 & 5.16 & 32.54 & 5.23 & 5.19 \\
\hline $\mathrm{P}_{4} \times \mathrm{L}_{1}$ & 640.45 & 52.71 & 60.71 & 21.48 & 14.74 & 3.02 & 90.25 & 5.50 & 31.12 & 6.87 & 3.83 \\
\hline $\mathrm{P}_{4} \times \mathrm{L}_{3}$ & 522.43 & 59.54 & 66.73 & 20.31 & 16.81 & 3.45 & 97.77 & 4.18 & 37.98 & 6.15 & 5.05 \\
\hline $\mathrm{P}_{4} \times \mathrm{L}_{2}$ & 490.69 & 62.79 & 75.11 & 18.01 & 19.13 & 2.35 & 108.70 & 3.76 & 38.71 & 7.71 & 4.37 \\
\hline $\mathrm{P}_{5} \times \mathrm{L}_{1}$ & 556.30 & 67.62 & 74.57 & 11.75 & 18.91 & 2.48 & 83.31 & 8.11 & 27.07 & 4.70 & 14.12 \\
\hline $\mathrm{P}_{5} \mathrm{X} \mathrm{L}_{3}$ & 527.66 & 63.31 & 68.77 & 10.09 & 20.88 & 2.95 & 79.59 & 6.21 & 24.23 & 4.81 & 10.54 \\
\hline $\mathrm{P}_{5} \mathrm{x} \mathrm{L}_{2}$ & 512.21 & 70.21 & 77.56 & 13.19 & 21.93 & 2.45 & 93.38 & 6.67 & 23.71 & 5.25 & 11.19 \\
\hline $\mathrm{P}_{6} \mathrm{x} \mathrm{L}_{1}$ & 725.25 & 56.64 & 62.59 & 14.35 & 17.01 & 2.86 & 75.11 & 6.25 & 38.88 & 5.61 & 4.97 \\
\hline $\mathrm{P}_{6} \mathrm{X} \mathrm{L}_{3}$ & 685.50 & 58.78 & 64.07 & 16.51 & 21.98 & 2.22 & 76.95 & 5.05 & 33.51 & 7.21 & 5.23 \\
\hline $\mathrm{P}_{6} \mathrm{X} \mathrm{L}_{2}$ & 640.77 & 68.92 & 76.18 & 16.01 & 22.27 & 1.95 & 87.67 & 4.71 & 39.61 & 6.62 & 3.98 \\
\hline $\mathrm{P}_{7} \times \mathrm{L}_{1}$ & 514.56 & 63.34 & 71.44 & 22.64 & 20.15 & 2.36 & 80.48 & 5.91 & 38.10 & 5.86 & 8.91 \\
\hline $\mathrm{P}_{7} \times \mathrm{L}_{3}$ & 495.95 & 63.48 & 68.71 & 22.94 & 23.97 & 2.59 & 85.33 & 5.46 & 37.18 & 5.07 & 4.27 \\
\hline $\mathrm{P}_{7} \times \mathrm{L}_{2}$ & 575.70 & 67.91 & 75.41 & 20.20 & 24.62 & 2.47 & 99.29 & 5.98 & 40.15 & 5.37 & 5.92 \\
\hline $\mathrm{P}_{8} \times \mathrm{L}_{1}$ & 536.20 & 50.63 & 59.71 & 25.30 & 16.95 & 2.91 & 81.24 & 6.93 & 28.11 & 6.01 & 4.06 \\
\hline $\mathrm{P}_{8} \mathrm{X} \mathrm{L}_{3}$ & 550.19 & 52.39 & 58.15 & 24.96 & 19.21 & 2.60 & 79.22 & 5.68 & 23.64 & 5.71 & 12.78 \\
\hline $\mathrm{P}_{8} \mathrm{X} \mathrm{L}_{2}$ & 558.85 & 60.91 & 67.73 & 19.48 & 18.51 & 2.18 & 74.07 & 5.57 & 24.47 & 5.02 & 9.35 \\
\hline $\mathrm{P}_{9} \times \mathrm{L}_{1}$ & 529.36 & 49.11 & 58.47 & 19.37 & 14.75 & 3.11 & 82.59 & 5.43 & 31.71 & 6.81 & 6.20 \\
\hline $\mathrm{P}_{9} \times \mathrm{L}_{3}$ & 502.47 & 50.47 & 59.12 & 17.31 & 15.85 & 2.97 & 75.31 & 5.69 & 29.15 & 7.37 & 4.77 \\
\hline $\mathrm{P}_{9} \mathrm{x} \mathrm{L}_{2}$ & 482.25 & 64.31 & 70.55 & $16 . .41$ & 15.03 & 2.35 & 79.17 & 5.96 & 27.71 & 7.96 & 5.25 \\
\hline $\mathrm{P}_{10} \times \mathrm{L}_{1}$ & 536.36 & 55.87 & 63.79 & 16.76 & 17.32 & 2.90 & 86.78 & 8.75 & 33.61 & 7.49 & 7.44 \\
\hline $\mathrm{P}_{10} \times \mathrm{L}_{3}$ & 522.22 & 62.51 & 71.84 & 14.27 & 18.14 & 2.98 & 73.56 & 8.21 & 35.61 & 6.95 & 4.92 \\
\hline
\end{tabular}




\begin{tabular}{|c|c|c|c|c|c|c|c|c|c|c|c|}
\hline $\mathrm{P}_{10} \times \mathrm{L}_{2}$ & 508.78 & 67.43 & 76.77 & 15.97 & 16.86 & 2.03 & 85.62 & 6.03 & 38.19 & 7.20 & 6.90 \\
\hline $\mathrm{P}_{1}$ & 509.64 & 58.32 & 66.91 & 19.01 & 16.96 & 2.15 & 68.62 & 6.31 & 29.62 & 6.19 & 5.38 \\
\hline $\mathrm{P}_{2}$ & 498.79 & 63.67 & 70.22 & 16.50 & 17.87 & 2.32 & 74.18 & 5.99 & 27.04 & 6.65 & 5.01 \\
\hline $\mathrm{P}_{3}$ & 525.72 & 71.25 & 76.15 & 14.15 & 18.05 & 2.61 & 87.74 & 6.12 & 31.55 & 5.10 & 7.92 \\
\hline $\mathrm{P}_{4}$ & 555.12 & 65.49 & 73.15 & 18.34 & 16.56 & 2.69 & 89.45 & 4.19 & 33.36 & 6.38 & 6.12 \\
\hline $\mathrm{P}_{5}$ & 536.14 & 68.21 & 74.62 & 12.62 & 17.07 & 2.57 & 81.12 & 6.40 & 28.11 & 4.95 & 6.76 \\
\hline $\mathrm{P}_{6}$ & 580.75 & 64.98 & 69.34 & 15.56 & 19.00 & 2.35 & 74.45 & 5.48 & 30.85 & 6.63 & 5.81 \\
\hline $\mathrm{P}_{7}$ & 542.30 & 62.84 & 70.11 & 20.37 & 19.70 & 2.28 & 86.47 & 5.19 & 35.68 & 5.25 & 5.17 \\
\hline $\mathrm{P}_{8}$ & 562.17 & 58.63 & 64.89 & 22.35 & 17.15 & 2.44 & 78.82 & 4.79 & 28.02 & 5.86 & 7.11 \\
\hline $\mathrm{P}_{9}$ & 537.21 & 57.53 & 63.31 & 17.50 & 13.02 & 2.52 & 75.40 & 5.10 & 26.59 & 6.90 & 6.97 \\
\hline $\mathrm{P}_{10}$ & 517.42 & 59.87 & 65.19 & 15.80 & 15.33 & 2.21 & 83.27 & 6.81 & 31.63 & 6.52 & 5.57 \\
\hline $\mathrm{L}_{1}$ & 560.96 & 59.67 & 67.22 & 21.17 & 16.61 & 2.65 & 80.84 & 6.75 & 28.72 & 5.28 & 5.83 \\
\hline $\mathrm{L}_{3}$ & 545.40 & 63.62 & 69.51 & 19.58 & 18.94 & 2.75 & 88.94 & 6.15 & 32.38 & 6.62 & 6.24 \\
\hline $\mathrm{L}_{2}$ & 504.80 & 71.00 & 77.67 & 14.51 & 20.06 & 2.10 & 91.25 & 5.34 & 34.82 & 7.02 & 6.79 \\
\hline $\mathrm{SE}(\mathrm{m}) \pm$ & 0.23 & 0.39 & 0.11 & 0.14 & 0.34 & 0.15 & 0.36 & 0.29 & 0.18 & 0.64 & 0.13 \\
\hline CD at $5 \%$ & 10.24 & 2.74 & 3.14 & 0.16 & 1.47 & 0.12 & 3.84 & 0.13 & 2.28 & 0.14 & 0.70 \\
\hline
\end{tabular}

Table.2 Analysis of variance for the design of experiment for fruit yield and related horticultural traits in triple test cross progenies of AN (L1) and SN (L2)

\begin{tabular}{|c|c|c|c|c|c|c|c|c|c|c|c|c|}
\hline Treatments & df & $\begin{array}{l}\text { Marketable } \\
\text { fruit yield/ } \\
\text { plant (g) }\end{array}$ & $\begin{array}{l}\text { Days to } \\
50 \text { per } \\
\text { cent } \\
\text { flowering }\end{array}$ & $\begin{array}{l}\text { Days to } \\
\text { first } \\
\text { picking }\end{array}$ & $\begin{array}{c}\text { Number of } \\
\text { marketable } \\
\text { fruits } \\
\text { per plant }\end{array}$ & $\begin{array}{c}\text { Fruit } \\
\text { length } \\
(\mathrm{cm})\end{array}$ & $\begin{array}{l}\text { Fruit } \\
\text { dia- } \\
\text { meter } \\
(\mathrm{cm})\end{array}$ & $\begin{array}{l}\text { Plant } \\
\text { height } \\
\text { (cm) }\end{array}$ & $\begin{array}{l}\text { Number } \\
\text { of } \\
\text { branches } \\
\text { per } \\
\text { plant }\end{array}$ & $\begin{array}{l}\text { Fruit } \\
\text { weight } \\
\text { (g) }\end{array}$ & $\begin{array}{l}\text { Pedicel } \\
\text { length } \\
(\mathrm{cm})\end{array}$ & $\begin{array}{c}\text { Bacterial } \\
\text { wilt } \\
\text { incidence } \\
(\%)\end{array}$ \\
\hline Replicates & 2 & 517.167 & 1.30 & 2.14 & 35.489 & 7.493 & 0.013 & 9.785 & 0.011 & 1.137 & 0.028 & 0.288 \\
\hline Treatments & 42 & $1077.047 * *$ & 97.870 ** & $118.40 * *$ & $18.265 * *$ & $\begin{array}{c}10.561 \\
* *\end{array}$ & $\begin{array}{l}0.106 \\
* *\end{array}$ & $\begin{array}{l}89.676 \\
* *\end{array}$ & $0.360 * *$ & $\begin{array}{l}23.295 \\
* *\end{array}$ & $\begin{array}{l}0.502 \\
* *\end{array}$ & $30.836^{* *}$ \\
\hline Error & 84 & 39.390 & 2.82 & 3.79 & 0.967 & 0.826 & 0.006 & 5.554 & 0.006 & 1.967 & 0.008 & 0.199 \\
\hline
\end{tabular}


Table.3 Analysis of variance for epistasis i, j \& 1 and D \&H components for different characters in TTC progenies of AN (L1) and SN (L2)

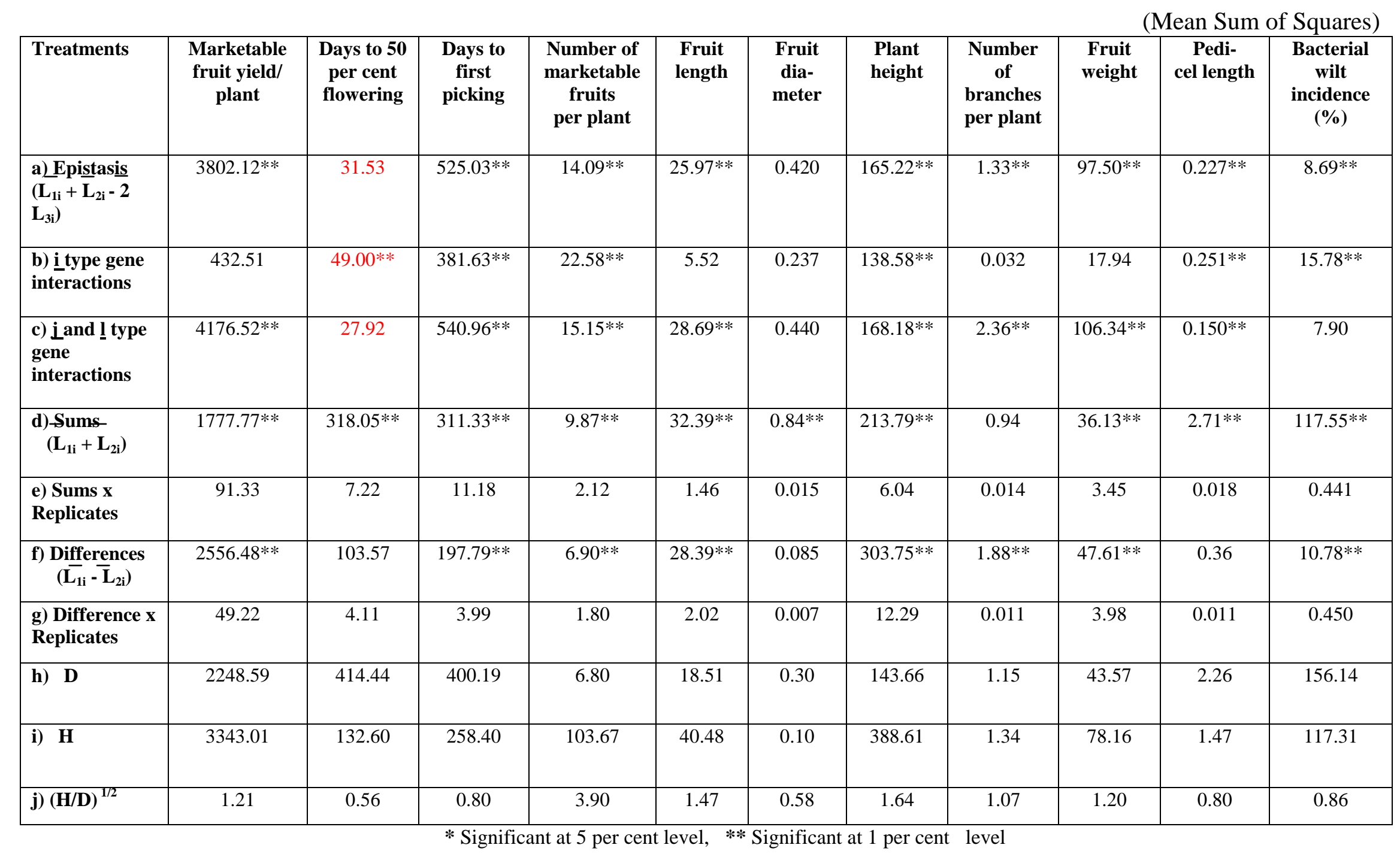


Darrah and Hallauer (1972) suggested that non-additive interactions are more important for components of yield rather than plant characteristics. Since $(j+l)$ type epistasis is more useful for hybrid development. This table also indicate that the variances due to sums $\left(\mathrm{L}_{1 \mathrm{i}}+\mathrm{L}_{2 \mathrm{i}}\right)$ were used for estimating additive (D) component of genetic variation, whereas the variances due to difference $\left(\mathrm{L}_{1 \mathrm{i}}-\right.$ $\mathrm{L}_{2 \mathrm{i}}$ ) were used for estimation of dominance (H) component. The importance of additive and dominance components of variation were reported for fruit yield and its components traits in brinjal by Thangavel et al., (2011), Chourasia and Shree (2012), Sidhu et al., (2012), Arunkumar et al., (2013) and Uddin et al., (2015). The degree of dominance $(H / D)^{1 / 2}$ was in the range of over dominance marketable fruit yield per plant, number of marketable fruits per plant, fruit length $(\mathrm{cm})$, plant height $(\mathrm{cm})$, number of branches per plant and fruit weight $(\mathrm{g})$.

However the presence of partial dominance for, days to 50 per cent flowering, days to first picking, fruit diameter $(\mathrm{cm})$, pedicel length (cm) and bacterial wilt incidence. These results are also in line with Kafytullah (2011) in brinjal. This suggests that heterosis breeding and reciprocal recurrent selection would be an appropriate procedure for the improvement of these characters. Recurrent selection procedures may be useful in the sense that it will exploit both additive and non-additive components of genetic variation for bringing about improvement in yield and its related attributes. Such a strategy will help increase frequency of favourable alleles while maintaining genetic variation in breeding population (Doerksen et al., 2003).

In conclusion, the triple test cross showed that the additive, dominance and epistasis gene actions were important in the inheritance of different characters. Under such a situation triple test cross mating as well as mating of selected plants in early segregating generations could be attempted for developing potential populations having optimum levels of homozygosity and heterozygosity. Although, transgressive segregants can be isolated by alternative intermating and subsequent handling of segregating generations in order to obtain high yielding stable lines in brinjal where all the three kinds of gene effects are present.

\section{References}

Arunkumar, B., Kumar, S.V.S. and Prakash, J.C. 2013. Genetic variability and divergence studies in brinjal (Solanum melongena L.). Bioinfolet, 10(2b): 6.

Chourasia, H.K. and Shree, S. 2012. Genetic variability in quantitative characters of brinjal (Solanum melongena L.). J. Interacademicia, 16(2): 196-202.

Dhameliya, H.R. and Dobariya, K.I. 2007. Estimation of components of genetic variance in full-sib progenies of brinjal (Solanum melongena L.). Orissa $J$. Hort., 35(2): 73-77.

Doerksen, T., Kannenberg, L. and Lee, L. 2003. Effect of recurrent selection on combining abilitry in maize breeding populations. Crop Sci., 43: 1652-1658.

Gavade, R.T. and Ghadage, B.A. 2015. Genetic variability, heritability and genetic advance in segregating generation of brinjal (Solanum melongena L.). Bioinfolet - A Quarterly J. Life Sci., 12(1C): 325-328.

Indiresh, K.M., Shivashankar, K.T. and Kulkarni, R.S. 2005. Gene action for yield and its components in brinjal (Solanum melongena L.). Mysore J. Agri. Sci., 39(1): 50-56.

Kafytullah, Indiresh, K.M. and Santhosha, H.M. 2011. Genetic variability in brinjal (Solanum melongena L.). Environ. Ecol., 29(3B): 1686-1688.

Shinde, K.G. 2007. Gene action of fruit yield and its components in brinjal (Solanum 
melongena L.). Adv. Plant Sci., 20(1): 63-65

Sidhu, B.B., Dhatt, A.S. and Kumar, A. 2012. Studies on combining ability for yield and quality traits in brinjal (Solanum melongena L.). J. Hort. Sci., 7: 145151.

Singh, A.K., Rai, M., Pan, R.S. and Prasad, V.S.R.K. 2002. Combining ability of quantitative characters in brinjal (Solanum melongena L.). Veg. Sci., 29: 127-30.

Suneetha, Y., Kathiria, K.B., Patel, J.S., Patel, N.B., Kathiria, P.K. and Srinivas, T. 2006. Diallel analysis over seasons in egg plant (Solanum melongena L.). Res. Crops, 7(3): 774-781

Thangavel, P., Thirugnanakumar, S. and Baradhan, G. 2011. Studies on genetic variability, heritability and genetic advance in segregating generations of brinjal (Solanum melongena L.). Plant Arch., (1): 453-456

Uddin, M.S., Rahman, M.M., Hossain, M.M. and Khaleque, M.M.A. 2015. Combining Ability of Yield and Yield Components in Eggplant (Solanum melongena L.) during summer. Univ. J. Plant Sci., 3(4): 59-66

\section{How to cite this article:}

Smita Kumari, K.S. Chandel and Aachal Chauhan. 2017. Triple Test Cross for Yield and Quantitative Components in Brinjal (Solanum melongena L.). Int.J.Curr.Microbiol.App.Sci. 6(5): 903-911. doi: https://doi.org/10.20546/ijcmas.2017.605.100 